\title{
Elemental Composition of Indoor Particulate Matter in Response to Heating Facility at Sakaka City, Saudi Arabia
}

\author{
Hesham Al-Jeelani \\ Department of Environmental Sciences, Faculty of Meteorology, Environment and Arid Land \\ Agriculture, King Abdulaziz University, Jeddah, Saudi Arabia.
}

\begin{abstract}
Indoor and outdoor airborne particulate matter $\left(\mathrm{PM}_{10}\right.$ and $\left.\mathrm{PM}_{2.5}\right)$ were sampled from homes with different heating facilities, located at Sakaka city, northern of Saudi Arabia during winter season. Elemental composition of $\mathrm{PM}_{10}$ and $\mathrm{PM}_{2.5}$ samples, including $\mathrm{Al}, \mathrm{Ba}, \mathrm{Be}, \mathrm{Ca}, \mathrm{Cd}, \mathrm{Co}, \mathrm{Cr}, \mathrm{Fe}, \mathrm{Ga}, \mathrm{K}, \mathrm{Li}, \mathrm{Mg}, \mathrm{Mn}, \mathrm{Na}$, $\mathrm{Ni}, \mathrm{Pb}, \mathrm{Se}, \mathrm{Te}$ and $\mathrm{Tl}$, were analyzed using inductively coupled plasma-mass spectroscopy (ICP-MS). Black carbon (BC) was also measured using EEL-type Smoke Stain Reflectometer. Results showed that the highest indoor concentration $\mathrm{PM}_{2.5}\left(541.67 \mu \mathrm{g} \mathrm{m}^{-3}\right)$ and $\mathrm{PM}_{10}\left(1201.39 \mu \mathrm{g} \mathrm{m}^{-3}\right)$ were found at homes using wood burning as heating facility. The most dominant metals were $\mathrm{Na}, \mathrm{Fe}$ and $\mathrm{Al}$ in the investigated $\mathrm{PM}_{2.5}$ and $\mathrm{PM}_{10}$ samples. The highest concentrations of black carbon were found in homes using wood burning as heating facility. For similar homes in heating facilities, we can deduce that by increasing the number of smoking persons the value of $\mathrm{BC}$ increased.
\end{abstract}

Keywords: PM2.5 and PM10, Indoor, Outdoor, Elemental composition, Black carbon, heating facilities,

Sakaka, Saudi Arabia.

\section{Introduction}

People spend most of their time (60-90\%) indoors (Nastov, et al., 2003; Yip et al., 2004). Therefore, good indoor air quality is very important to us. Children and women spend most of their time in indoor environments and are more exposed to pollution indoors than outdoors. Currently, there has been a rapid expansion of interest in indoor air quality and its contribution to total human exposure to air pollutants (Schneider, et al., 2003; Conner and Williams, 2004).

Each indoor micro-environment is uniquely characterized and determined by the local outdoor air, specific building characteristics and indoor activities (Stranger, et al., 2007). Consequently, each individual's personal exposure will be determined by a combination of the local outdoor pollutant levels and the different indoor micro-environments to which $\mathrm{s} / \mathrm{he}$ is exposed to, and their residence time. There are hundreds of pollutants which affect indoor air quality and thousands of sources (Hays, et al., 1995, Chenchen, et al., 2016). In homes, there are many indoor sources of particulate and gaseous air pollutants, including combustion processes, clothing fibers, building materials and furnishings, wet or damp carpet, cabinetry or furniture made of 
certain pressed wood products, products for house hold cleaning and maintenance, personal care or hobbies detergent solution and pesticides, central heating and cooling systems and humidification devices, and outdoor sources (U.S.EPA, 1996; Abdul-Wahab, 2006, Aneesa, et al., 2015).

Several studies have shown the impact of outdoor air on the indoor environment (Srivastava and Jain, 2003, Nastov et al., 2003, Anna et al., 2014, Reto et al., 2015, Peiyao et al., 2015).In many studies, it has been shown that outdoor and indoor pollutant concentration levels correlate with each other (Paschold, et al., 2003; Bae, et al., 2004; Kornartit, et al., 2010). However, there are cases where a considerable amount of air pollution might have originated from indoor activities alone (Chao and Wong, 2002; Branis, et al., 2005). In addition, the air within the buildings can be more seriously polluted than the outdoor air in even the largest and most industrialized city (Lee, et al., 2002).

There is a lack of information on the indoor levels of particulate $\mathrm{PM}_{2.5}$ and $\mathrm{PM}_{10}$ and their chemical composition in homes in Saudi Arabia. Therefore, the present study aimed to fill the above mentioned gap of knowledge by evaluating the indoor concentrations, elemental composition and black carbon of $\mathrm{PM}_{2.5}$ and $\mathrm{PM}_{10}$ in homes with different heating facilities at Sakaka city, Saudi Arabia, and to compare these concentrations with ambient air levels. In addition, the factors that had an effect on the indoor levels PM2.5 and PM10 and their chemical composition were measured.

\section{Materials and Methods}

Study area

Sakaka is located at the north of Saudi Arabia kingdom, with the latitude as N 59 $29^{\circ}$ and longitude as E $40^{\circ} 12^{\prime}$ '. Its area and population are $8053 \mathrm{~km}^{2}$ and 242,813, respectively. Most of commercial activities are concentrated in the city center which defined as residential and government working area. All the investigated sites were near this area as shown in Figure (1). In winter of 2014-2015, the average relative humidity and wind speed were $40.7 \%$ and $12 \mathrm{~km} / \mathrm{h}$, respectively. Indoors and outdoors particulate $\mathrm{PM}_{10}$ and $\mathrm{PM}_{2.5}$ were collected at different homes using different heating facilities (Table 1) during winter season (December 2014-March 2015).

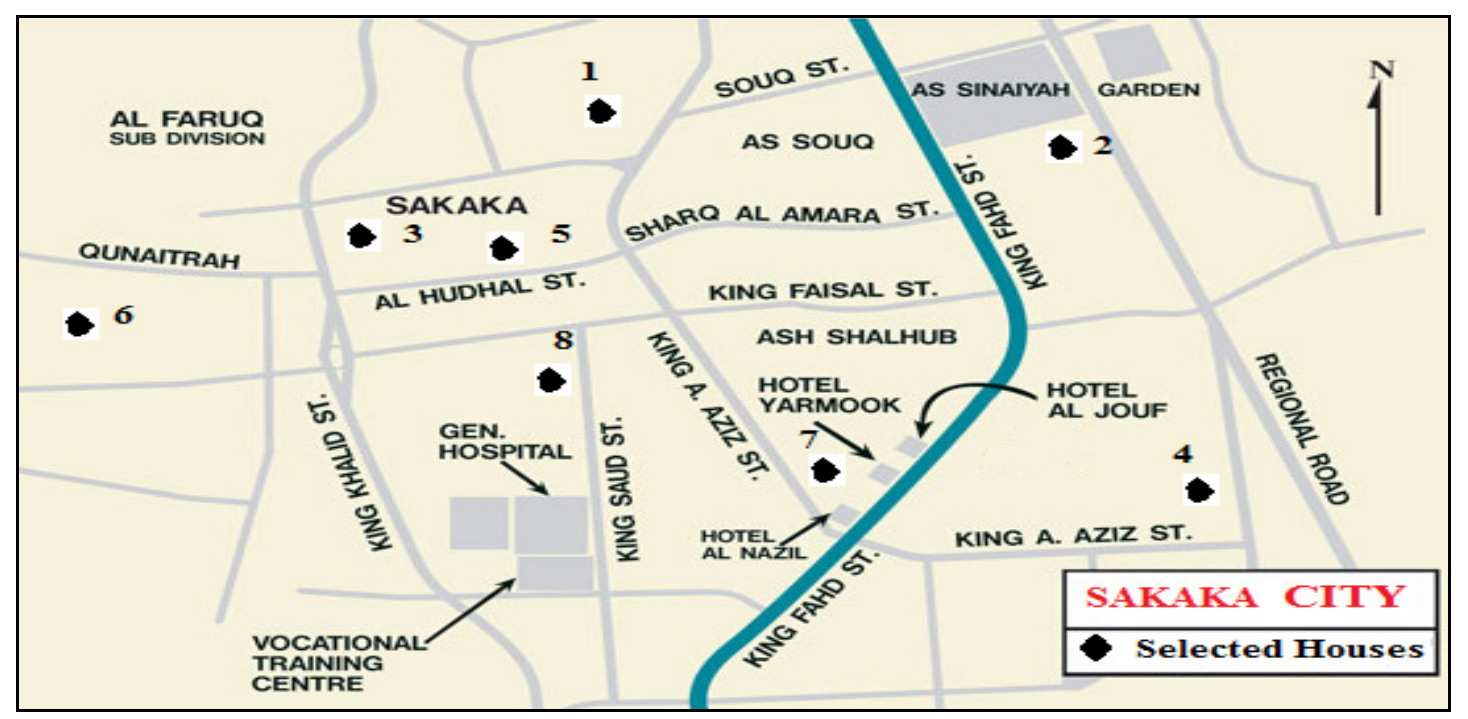

Fig. 1. Selected homes at Sakaka city. 
Table 1. The used home heating facilities at the different investigated homes.

\begin{tabular}{|l|l|}
\hline Home & Home heating facility \\
\hline 1 & Air conditioner \\
\hline 2 & Wood fire \\
\hline 3 & Gas heater\& Air conditioner \\
\hline 4 & Electrical heater\& Air conditioner \\
\hline 5 & Air conditioner \\
\hline 6 & Wood fire \\
\hline 7 & absent \\
\hline 8 & absent \\
\hline
\end{tabular}

\section{Sampling}

Particulate $\mathrm{PM}_{2.5}$ and $\mathrm{PM}_{10}$ samples were collected on membrane quartz filters $37 \mathrm{~mm}$ in diameter, using calibrated pump (Leland Legacy Sample Pump from SKC) with $\mathrm{PM}_{2.5}$ and $\mathrm{PM}_{10}$ inlets operated at constant flow rate $(101 / \mathrm{min}$.) and programmed to collect $24 \mathrm{~h}$ samples. The filters were weighed before sampling on an analytical balance. At the end of sampling period, the filters were reweighed to calculate weight and concentrations of particulates in air $\left(\mu \mathrm{g} / \mathrm{m}^{3}\right)$.

\section{Elemental Analysis}

All filters were digested in $5 \mathrm{ml}$ concentrated nitric acid and $2 \mathrm{ml}$ of hydrochloric acid at $120^{\circ}-200^{\circ} \mathrm{C}$ using sand bath and then diluted to $5 \mathrm{ml}$ (Fernandez, et $a l ., 2000)$. The extracted solution was filtered, using a Whatman no 41 filter, completed to 5 $\mathrm{ml}$ with distilled-deionized water. After digestion, an inductively coupled plasma atomic emission spectrometer (Shimadzu ICPE-9000) was used to measure the trace metal concentration including $\mathrm{Al}, \mathrm{Ba}, \mathrm{Be}, \mathrm{Ca}$, $\mathrm{Cd}, \mathrm{Co}, \mathrm{Cr}, \mathrm{Fe}, \mathrm{Ga}, \mathrm{K}, \mathrm{Li}, \mathrm{Mg}, \mathrm{Mn}, \mathrm{Na}, \mathrm{Ni}, \mathrm{Pb}$, $\mathrm{Se}, \mathrm{Te}$ and Tl. The background contamination was routinely monitored using operational blanks (unexposed filters) that were processed simultaneously with field samples.

\section{Black carbon}

Black carbon (BC) was measured using EEL-type Smoke Stain Reflectometer
(Diffusion Systems, Ltd). Secondary standards of known black carbon concentrations were used to calibrate the reflectometer (Biswas, et al., 2003). The concentrations are defined based on the amount of reflected light that is absorbed by the filter sample and an assumed mass absorption coefficient. It is related to the concentration of light absorbing carbon through standards of carbon with a known areal density.

\section{Results and discussion}

\section{Particulate PM 2.5 and PM 10 concentrations}

Indoor concentrations of $\mathrm{PM}_{2.5}$ and $\mathrm{PM}_{10}$ in different homes are illustrated in Figures (2\&3). The highest concentrations were $541.67 \mu \mathrm{g} \mathrm{m}^{-3}$ and $201.39 \mu \mathrm{g} \mathrm{m}^{-3}$ for $\mathrm{PM}_{2.5}$ and $\mathrm{PM}_{10}$, respectively. These highest concentrations were recorded at homes that use wood burning as heating facility (location $2 \& 6$ at Figure 1)

The indoor guidelines for $\mathrm{PM}_{2.5}$ are variable within the few countries that already defined such regulation (Stranger, et al., 2007). The limit value varies between $15 \mathrm{mg} \mathrm{m}^{-3}$ (averaged over one year) in Belgium (Decree of The Flemish Government, 2004), $25 \mathrm{mg} \mathrm{m}^{-3}$ (averaged over $8 \mathrm{~h}$ ) in Portugal (Portaria $\mathrm{n}^{\circ}$ 353-A/2013 de 4 de Dezembro, 2013) and 40 $\mathrm{mg} \mathrm{m}^{-3}$ (averaged over $1 \mathrm{~h}$ ) in Canada.

The levels of PM2.5 in the present study were higher than that reported in literature. John, et al. (2007) recorded mean concentrations of PM2.5 at urban, suburban and rural area in the states to be 16, 17 and 16 $\mu \mathrm{g} \mathrm{m} \mathrm{m}^{-3}$. Another study was conducted at Antwerp, Belgium and showed that the average indoor $\mathrm{PM}_{2.5}$ levels ranged from 54 to $72 \mu \mathrm{g} \mathrm{m}^{-3}$, on $12 \mathrm{~h}$ samples (Stranger, et al., 2008). In Stockholm, a study of the chemical characterization of $\mathrm{PM}_{2.5}$ concluded that $\mathrm{PM}_{2.5}$ concentrations in indoors ranged from 3.9 to $19 \mu \mathrm{g} \mathrm{m}^{-3}$, on $6 \mathrm{~h}$ samples (Molnár, et al., 2007), Fromme, et al. (2008) focused his study 
in the particulate matter and found mean $\mathrm{PM}_{2.5}$ indoor values of $37 \mu_{\mathrm{g} \mathrm{m}}^{-3}$, (5 h per day).

The higher concentrations of $\mathrm{PM}_{2.5}$ measured in the present study can be associated with the existence of wood burning process used as heating facility in homes (sites $2 \& 6$ ). In fact, the wood burning process is the main distinguishable factor and it has been reported that the biomass combustion is a major source of $\mathrm{PM}_{2.5}$ (Reisen, et al., 2013; Molnár, et al., 2005).

The outdoor concentrations of $\mathrm{PM}_{10}$ and $\mathrm{PM}_{2.5}$ monitored at the selected homes are presented graphically in Figures (2\&3). The highest outdoor concentrations of PM2.5 and PM10 were recorded at home 5 during dust storm. They were $368.06 \mu \mathrm{g} \mathrm{m}^{-3}$ for $\mathrm{PM}_{2.5}$ and $437.50 \mu \mathrm{g} \mathrm{m}{ }^{-3}$ for $\mathrm{PM}_{10}$. Sakaka city is exposed to bouts of dust storm that lead to increase the levels of particulate matter fractions $\left(\mathrm{PM}_{2.5}\right.$ and $\left.\mathrm{PM}_{10}\right)$ in the atmosphere (Basheer and Naif, 2015).

The concentrations of outdoor $\mathrm{PM}_{2.5}$ and $\mathrm{PM}_{10}$ in the present study exceeded World Health Organization for both $\mathrm{PM}_{2.5}$ and $\mathrm{PM}_{10}$ daily averages of 25 and $50 \mu \mathrm{g} \mathrm{m} \mathrm{m}^{-3}$, respectively. The concentration of $\mathrm{PM}_{10}$ exceeded the European Union Air Quality Standard for daily average of $50 \mu \mathrm{g} \mathrm{m}^{-3}$ in all samples. However, in comparison with U.S. $24-\mathrm{hr}$ average standards, only $25 \%$ of $\mathrm{PM}_{10}$ samples exceeded the standard of $150 \mu \mathrm{g} \mathrm{m}^{-3}$, and all of $\mathrm{PM}_{2.5}$ samples exceeded the standard of $65 \mu \mathrm{g} \mathrm{m}^{-3}$. These results clearly indicated that the airborne particulate pollution has been high in Sakaka.

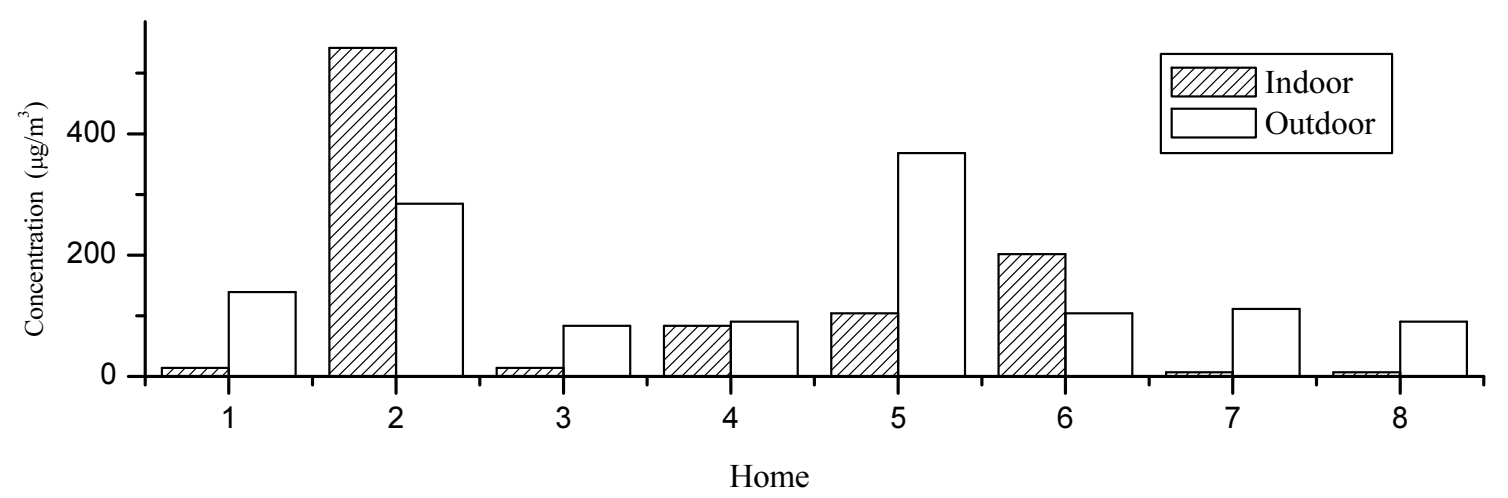

Fig. 2. Indoor and outdoor concentrations of $\mathrm{PM}_{2.5}$ at homes in Sakaka city during the period of study.

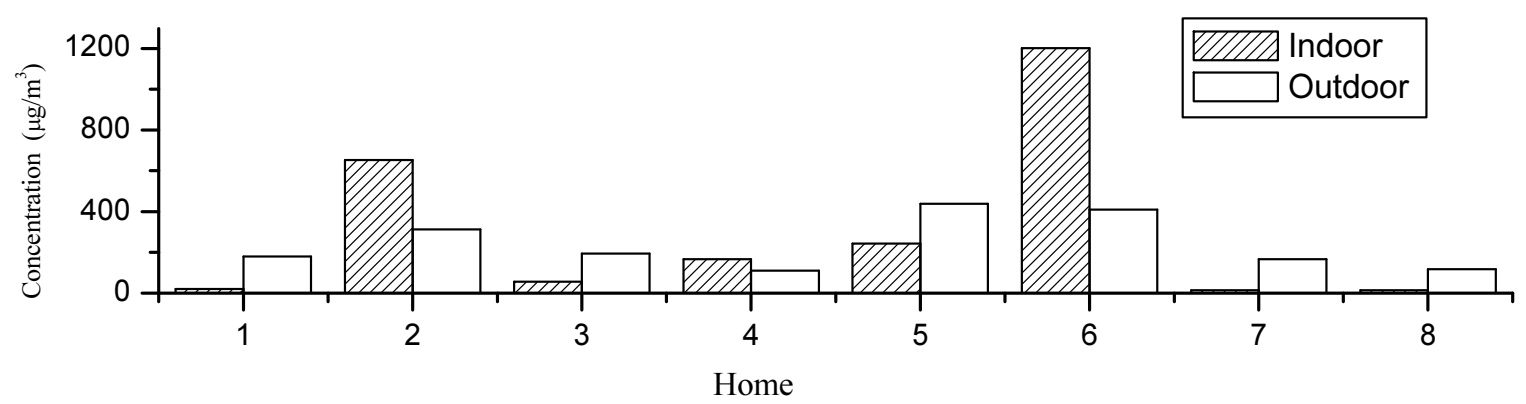

Fig. 3. Indoor and outdoor concentrations of $\mathrm{PM}_{10}$ at homes in Sakaka city during the period of study. 
Indoor/outdoor $\boldsymbol{P M}_{2.5}$ and $P M_{10}$ concentration ratios

Indoor/ Outdoor concentration ratios (I/O) for $\mathrm{PM}_{2.5}$ and $\mathrm{PM}_{10}$ at each selected home were calculated and presented graphically in Figure (4). From this figure, it is clear that the indoor $\mathrm{PM}_{2.5}$ and $\mathrm{PM}_{10}$ concentrations were higher than the corresponding levels outdoors at homes $(2 \& 6)$ where wood fire facility is used. Many studies have had contrasting results, finding low or high correlations between indoor and outdoor pollutant concentrations when sampling inside and directly outside of homes (Adgate et al., 2002; Ramachandran, et al., 2000). Levy et al. (2002) and Morawska et al. (2001) identified moderate to high $(\mathrm{I} / \mathrm{O})$ pollutant ratios.

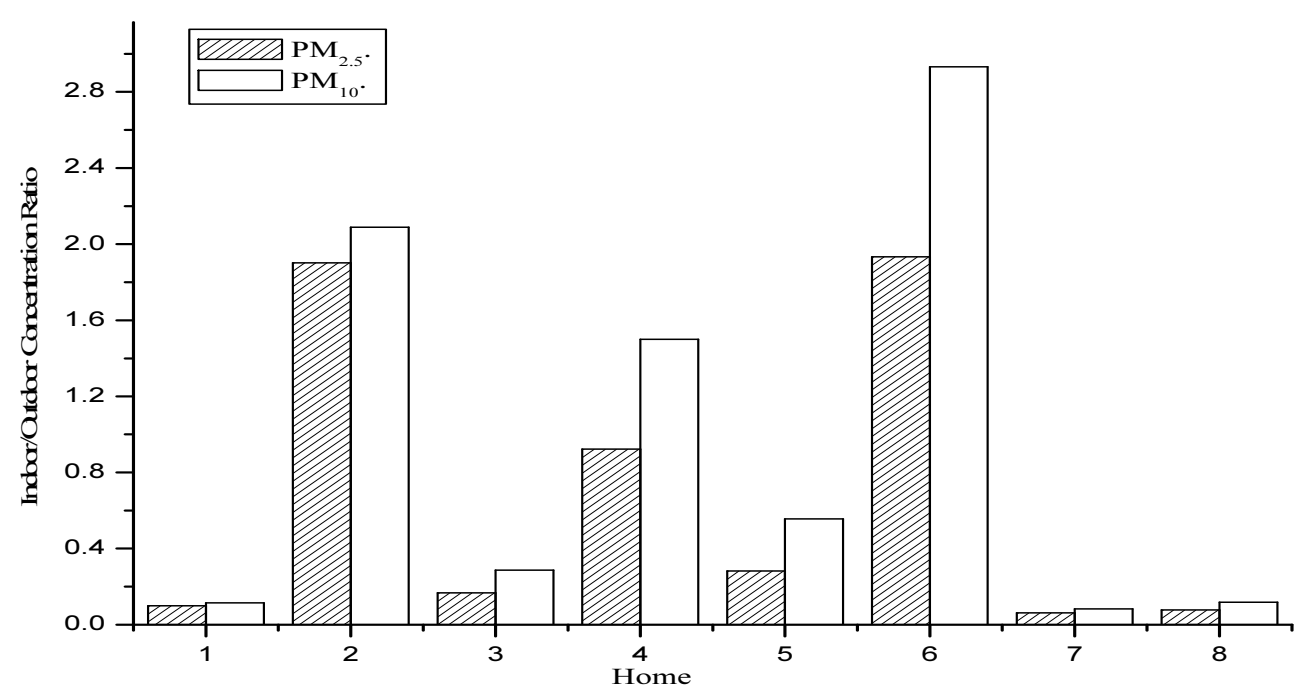

Fig. 2. Indoor and outdoor concentrations of $P M_{2.5}$ and $P M_{10}$ at homes in Sakaka city during the period of study.

\section{Elemental concentration of $\mathbf{P M}_{2.5}$ and $\mathbf{P M}_{10}$}

The trace element concentrations for indoor $\mathrm{PM}_{2.5}$ and $\mathrm{PM}_{10}$ fractions are shown in Table (2). The values were in the order as $\mathrm{Na}>\mathrm{Co}>\mathrm{Se}>$ $\mathrm{Al}>\mathrm{Fe}>\mathrm{Ni}>\mathrm{Li}>\mathrm{Te}>\mathrm{K}>\mathrm{Ga}>\mathrm{Cd}>\mathrm{Mn}>$ $\mathrm{Pb}>\mathrm{Be}=\mathrm{Tl}>\mathrm{Ba}>\mathrm{Cr}>\mathrm{Mg}>\mathrm{Ca}$ for $\mathrm{PM}_{2.5}$ fraction, whereas the order was $\mathrm{Mn}>\mathrm{K}>\mathrm{Na}>$ $\mathrm{Co}>\mathrm{Se}>\mathrm{Ca}>\mathrm{Fe}>\mathrm{Mg}>\mathrm{Ni}>\mathrm{Al}>\mathrm{Li}>\mathrm{Te}>$ $\mathrm{Tl}>\mathrm{Ga}>\mathrm{Cd}>\mathrm{Pb}>\mathrm{Ba}>\mathrm{Be}>\mathrm{Cr}$ for $\mathrm{PM}_{10} . \mathrm{Na}$ was the highest measured concentration (5375 $\mathrm{ng} / \mathrm{m}^{3}$ ) in the investigated $\mathrm{PM}_{2.5}$ samples, whereas $\mathrm{K}$ was the highest measured concentration $\left(13479 \mathrm{ng} / \mathrm{m}^{3}\right)$ for $\mathrm{PM}_{10}$ samples.

With regard to the outdoor, the trace elements concentrations for $\mathrm{PM}_{2.5}$ and $\mathrm{PM}_{10}$ fractions are showed in Table (3). For $\mathrm{PM}_{2.5}$ fraction, the values were in the order as $\mathrm{Fe}>\mathrm{Al}>\mathrm{Na}>\mathrm{Te}>$ $\mathrm{K}>\mathrm{Mg}>\mathrm{Ca}>\mathrm{Ga}>\mathrm{Mn}>\mathrm{Tl}>\mathrm{Se}>\mathrm{Ba}>\mathrm{Pb}>$ $\mathrm{Cr}>\mathrm{Ni}>\mathrm{Co}>\mathrm{Li}>\mathrm{Be}, \mathrm{Cd}$. For $\mathrm{PM}_{10}$, the order was $\mathrm{Na}>\mathrm{Fe}>\mathrm{Al}>\mathrm{Ca}>\mathrm{Te}>\mathrm{Mg}>\mathrm{K}>\mathrm{Mn}>$ $\mathrm{Tl}>\mathrm{Ga}>\mathrm{Se}>\mathrm{Ba}>\mathrm{Ni}>\mathrm{Pb}>\mathrm{Cr}>\mathrm{Co}>\mathrm{Li}, \mathrm{Be}$, $\mathrm{Cd}$. Among of these trace elements, heavy metals were of major concern because of their toxicity. Heavy metals could enter into human body via directly inhalation, affecting central nervous system and acting as cofactors in other diseases, especially for young children who were more sensitive than adults. For example, lead was related to kidney disease, peripheral neuropathy and encephalopathy; kidney was the main target for $\mathrm{Cd}$ and it can cause osteomalacia or osteoporosis; $\mathrm{Mn}, \mathrm{Co}, \mathrm{Cu}$ and $\mathrm{Pb}$ were initiators or promotors of carcinogenic activities 
in animals; $\mathrm{Cr}$ was neurological, renal and developmental toxicant at certain concentrations (Gupta, et al., 2007).

In the present study, Fe was one of the major contributors to the sampled $\mathrm{PM}_{2.5}$. In Stockholm (Molnár, et al., 2007), a study of the chemical characterization of $\mathrm{PM}_{2.5}$ concluded that Fe and $\mathrm{K}$ were among the elements with the largest contribution to the aerosol.

\section{Black carbon}

Black carbon is a good indicator of combustion-related air pollution. The concentrations of black carbon in the present study are listed in Table (4). The high concentration of $\mathrm{BC}$ was in homes (2\&6) where wood burning was used as the heating facility. For similar homes in heating facilities (1\&5) we can deduce that by increasing the number of smoking persons the value of $\mathrm{BC}$ increased. Effects related with $\mathrm{BC}$ emissions included oxidative stress, inflammation, lipid peroxidation and atherosclerosis, change in heart rate variability, arrhythmias, ST-segment depression (heart function), and changes in vascular function (such as blood pressure) (Grahame \& Schlesinger, 2010).

Table 2. Elemental concentrations in indoor samples within $P M_{2.5}$ and $P_{10}$ fractions $\left(\mathrm{ng} / \mathrm{m}^{3}\right)$.

\begin{tabular}{|c|c|c|c|c|c|c|c|c|c|c|c|c|c|c|c|c|c|c|}
\hline & \multicolumn{9}{|c|}{$\mathrm{PM}_{2.5}$} & \multicolumn{9}{|c|}{$\mathrm{PM}_{10}$} \\
\hline Site & 1 & 2 & 3 & 4 & 5 & 6 & 7 & 8 & M & 1 & 2 & 3 & 4 & 5 & 6 & 7 & 8 & M \\
\hline $\mathrm{Al}$ & ND & 447.1 & ND & ND & ND & 1174 & 284 & 54.2 & 244.9 & 1609 & 830.4 & 81.7 & ND & 824.2 & 72.5 & ND & ND & 427.2 \\
\hline $\mathrm{Ba}$ & ND & ND & ND & ND & ND & ND & 15.0 & ND & 1.9 & 31.2 & 4.7 & 20 & ND & ND & ND & ND & ND & 7.0 \\
\hline $\mathrm{Be}$ & ND & ND & 0.1 & ND & ND & 19.3 & 1.5 & ND & 2.6 & 1.0 & 0.2 & 7.3 & 1.2 & 12.5 & 6.2 & ND & ND & 3.6 \\
\hline $\mathrm{Ca}$ & ND & ND & ND & ND & ND & ND & ND & ND & 0.0 & 3183 & 395.8 & ND & ND & ND & ND & ND & ND & 447.4 \\
\hline $\mathrm{Cd}$ & 9.8 & 0.4 & ND & ND & ND & 89.6 & 0.1 & ND & 12.5 & 2.5 & 8.3 & 28.8 & ND & 64.6 & 63.3 & ND & ND & 20.9 \\
\hline Co & ND & 1.5 & ND & ND & ND & 8300 & ND & ND & 1037.7 & 5.7 & 1.0 & 1570 & ND & 6133 & 3087 & ND & ND & 1349.6 \\
\hline $\mathrm{Cr}$ & ND & ND & ND & ND & ND & ND & 8.1 & ND & 1.0 & 19.1 & 4.9 & ND & 2.4 & ND & ND & 1.4 & ND & 3.5 \\
\hline $\mathrm{Fe}$ & ND & 865 & 12.5 & 40.8 & ND & ND & 632 & 143 & 211.7 & 1377 & 1582 & ND & ND & ND & 0.1 & 302 & 186 & 430.9 \\
\hline $\mathrm{Ga}$ & ND & ND & 2.75 & 16.8 & ND & 8.3 & 223 & 31.8 & 35.3 & ND & ND & 2.20 & ND & 5.5 & 4.6 & 78.0 & 88.8 & 22.4 \\
\hline K & ND & ND & ND & ND & ND & 10.5 & 304 & ND & 39.3 & ND & 13479 & 11.8 & ND & 20.7 & 15.0 & ND & ND & 1690.8 \\
\hline $\mathrm{Li}$ & ND & 0.8 & ND & ND & ND & 1563 & ND & ND & 195.5 & 22.9 & ND & 62.5 & ND & 1142.9 & 78.8 & ND & ND & 163.4 \\
\hline $\mathrm{Mg}$ & ND & ND & ND & ND & ND & 0.8 & ND & ND & 0.1 & 2191 & ND & ND & ND & 24.3 & ND & ND & ND & 276.9 \\
\hline $\mathrm{Mn}$ & 38.9 & 17.3 & ND & ND & ND & 30.0 & 12.6 & ND & 12.4 & 66.7 & 34.6 & 69.6 & ND & 508 & 15041 & 4.6 & ND & 1965.6 \\
\hline $\mathrm{Na}$ & 21.7 & 2429 & 579.2 & 695 & 420 & 3877 & ND & 5375 & 1674.6 & ND & ND & 1839 & 305.8 & 2956 & 1839 & 4625 & ND & 1445.6 \\
\hline $\mathrm{Ni}$ & ND & ND & ND & ND & ND & 1650 & 1.3 & ND & 206.4 & 16.3 & 3.3 & 323 & ND & 1291 & 504 & ND & ND & 267.2 \\
\hline $\mathrm{Pb}$ & ND & 5.3 & ND & ND & ND & 37.0 & 2.1 & ND & 5.6 & 31.7 & 7.1 & ND & ND & 24.5 & 2.1 & ND & ND & 8.2 \\
\hline $\mathrm{Se}$ & 21.7 & 4.6 & ND & ND & ND & 3877 & ND & ND & 487.9 & 73.3 & 9.6 & 1839.6 & ND & 2956.3 & 1839.6 & ND & ND & 839.8 \\
\hline $\mathrm{Te}$ & ND & 662.9 & ND & ND & ND & ND & 412 & 67.9 & 142.9 & 987.9 & 75.8 & ND & ND & ND & ND & ND & ND & 133.0 \\
\hline $\mathrm{Tl}$ & ND & 3.3 & ND & ND & 1.3 & 16.0 & ND & ND & 2.6 & 155.0 & 9.2 & 1.2 & ND & 12 & 3.5 & ND & ND & 22.6 \\
\hline
\end{tabular}


Table 3. Elemental concentrations in outdoor samples within $\mathbf{P M}_{2.5}$ and $\mathbf{P M}_{10}$ fractions $\left(\mathrm{ng} / \mathrm{m}^{3}\right)$.

\begin{tabular}{|c|c|c|c|c|c|c|c|c|c|c|c|c|c|c|c|c|c|c|}
\hline & \multicolumn{9}{|c|}{$\mathrm{PM}_{2.5}$} & \multicolumn{9}{|c|}{$\mathrm{PM}_{10}$} \\
\hline Site & 1 & 2 & 3 & 4 & 5 & 6 & 7 & 8 & M & 1 & 2 & 3 & 4 & 5 & 6 & 7 & 8 & M \\
\hline $\mathrm{Al}$ & 3292 & 530 & ND & ND & ND & ND & 372 & 567 & 595.1 & 1355 & 222 & 3.3 & ND & ND & ND & 880.4 & 951 & 426.5 \\
\hline $\mathrm{Ba}$ & 9.9 & ND & ND & ND & ND & ND & 7.7 & 22.0 & 5.0 & 21.2 & ND & ND & ND & ND & ND & 12.5 & 19.5 & 6.7 \\
\hline $\mathrm{Be}$ & 0.3 & ND & 0.3 & 6.7 & ND & ND & ND & ND & 0.9 & ND & ND & ND & 7.5 & ND & ND & 0.1 & ND & 1.0 \\
\hline $\mathrm{Ca}$ & 712 & ND & ND & ND & ND & ND & 29.2 & 229 & 121.3 & 1520 & ND & ND & ND & ND & ND & 495.8 & 550 & 320.7 \\
\hline $\mathrm{Cd}$ & 1.9 & 0.6 & ND & 4.0 & ND & ND & ND & 0.4 & 0.9 & 1.3 & 0.3 & ND & 4.8 & ND & ND & 0.8 & 0.8 & 1.0 \\
\hline Co & 4.7 & 1.8 & ND & 5.1 & ND & ND & ND & 0.8 & 1.6 & 2.5 & 1.1 & ND & 5.6 & ND & ND & 1.8 & 1.3 & 1.5 \\
\hline $\mathrm{Cr}$ & 20.4 & ND & ND & ND & ND & ND & 2.3 & 6.5 & 3.7 & 10.0 & ND & ND & ND & ND & ND & 5.8 & 6.4 & 2.8 \\
\hline $\mathrm{Fe}$ & 4407 & 1019 & 50.4 & ND & ND & 207 & 977 & 1723 & 1047.9 & 2340 & 565 & 240 & ND & ND & 232 & 1748 & 1815 & 867.5 \\
\hline $\mathrm{Ga}$ & 21.8 & ND & 18.0 & ND & ND & ND & 198 & 239 & 59.6 & 5.8 & ND & 83.8 & ND & ND & ND & 6.0 & ND & 12.0 \\
\hline $\mathrm{K}$ & 1033 & ND & ND & ND & ND & ND & ND & 95.8 & 141.1 & 125 & ND & ND & ND & ND & ND & 225.0 & 254 & 75.5 \\
\hline $\mathrm{Li}$ & 3.2 & 0.6 & ND & 5.6 & ND & ND & ND & ND & 1.2 & 0.5 & 0.5 & ND & 6.5 & ND & ND & 0.5 & ND & 1.0 \\
\hline $\mathrm{Mg}$ & 1033 & ND & ND & ND & ND & ND & ND & ND & 129.1 & 325 & ND & ND & ND & ND & ND & 458 & ND & 97.9 \\
\hline $\mathrm{Mn}$ & 69.6 & 20.7 & ND & ND & ND & ND & 19.3 & 27.5 & 17.1 & 55.4 & 15.7 & 4.1 & ND & ND & ND & 39.6 & 43.3 & 19.8 \\
\hline $\mathrm{Na}$ & ND & 2845 & 820 & ND & 278 & 177 & ND & ND & 515.0 & 6458 & 1712 & 1358 & ND & 251 & 270.0 & ND & ND & 1256.1 \\
\hline $\mathrm{Ni}$ & 15.7 & 0.2 & ND & ND & ND & ND & 3.2 & 5.6 & 3.1 & 13.2 & ND & ND & 0.1 & ND & ND & 21.6 & 6.1 & 5.1 \\
\hline $\mathrm{Pb}$ & 23.4 & 6.8 & ND & ND & ND & ND & ND & 3.3 & 4.2 & 17.4 & 2.8 & ND & ND & ND & ND & 7.1 & 5.8 & 4.1 \\
\hline $\mathrm{Se}$ & 43.3 & 14.2 & ND & ND & ND & ND & ND & 3.8 & 7.7 & 35.4 & 1.3 & ND & ND & ND & ND & 19.6 & 12.5 & 8.6 \\
\hline $\mathrm{Te}$ & 271.3 & 787 & ND & ND & ND & 23 & 625 & 53.8 & 220.0 & 154 & 604 & 182 & ND & ND & 75.8 & 106.7 & 81.7 & 150.5 \\
\hline $\mathrm{Tl}$ & 36.7 & 7.1 & 6.7 & ND & 24.6 & ND & ND & 2.1 & 9.7 & 27.9 & ND & ND & ND & 10.4 & 35.4 & 15.8 & 9.6 & 12.4 \\
\hline
\end{tabular}

Table 4. Black carbon (BC) concentrations in indoor samples $\left(\mu \mathrm{g} / \mathrm{m}^{3}\right)$.

\begin{tabular}{|c|c|c|c|}
\hline Site & BC & Heating facility & Number of smokers \\
\hline 1 & 5.65 & Air conditioner & zero \\
\hline 2 & 89.34 & Wood fire & 2 \\
\hline 3 & 3.16 & Gas heater\& Air conditioner & 2 \\
\hline 4 & 12.72 & Electrical heater\& Air conditioner & 2 \\
\hline 5 & 15.56 & Air conditioner & 6 \\
\hline 6 & 98.65 & Wood fire & 2 \\
\hline 7 & 13.27 & absent & zero \\
\hline 8 & 3.16 & absent & \\
\hline
\end{tabular}




\section{Conclusions}

Field measurements were conducted to determine the levels of indoor $\mathrm{PM}_{2.5}$ and $\mathrm{PM}_{10}$ in homes where different heating facilities were used. The elements associated with indoor and outdoor $\mathrm{PM}_{2.5}$ and $\mathrm{PM}_{10}$ were investigated. Black carbon (BC) was also measured. The most dominant metals were $\mathrm{Na}$, Fe and Al. The highest indoor $\mathrm{PM}_{2.5}, \mathrm{PM}_{10}$ and $\mathrm{BC}$ concentrations were found in homes using wood burning as heating facility. The indoor $\mathrm{PM}_{2.5}$ and $\mathrm{PM}_{10}$ concentrations were higher than the corresponding levels outdoors at homes where wood fire facility is used.

\section{References}

Abdul-Wahab, S.A. (2006) Indoor and Outdoor Relationships of Atmospheric Particulates in Oman, Indoor and Built Environ., 15: 247-255.

Adgate, J., Ramachandran, G., Pratt, G., Waller, L. and Sexton, K. (2002) Spatial and temporal variability in outdoor, indoor, and personal $\mathrm{PM}_{2.5}$ exposure, Atmos. Environ., 36, p.3255.

Aneesa, V., Whitney, B., Polite, M. N., Robert, P. G., Peter, D. S. and Heather, J. Z. (2015) Home environment and indoor air pollution exposure in an African birth cohort study, Science of the Total Environment, 536: 362-367.

Anna, J. B., Agnieszka, K., Rene Van, G., Andrew, B., Gabriela, P., Karolien D., Sanja P. (2014) Composition of PM2.5 and PM1 on high and low pollution event days and its relation to indoor air quality in a home for the elderly, Science of the Total Environment, 490: 134-143.

Bae, H., Yang, W. and Chung, M. (2004) Indoor and outdoor concentrations of RSP, NO2 and selected volatile organic compounds at 32 shoe stalls located near busy roadways in Seoul, Korea, Sci. Total Environ., 323: 99-105.

Basheer, M. G. and Naif, S. A. (2015) Dust fall and suspended dust in Sakaka city, Cultural alsudairy center, $1^{\text {st }}$ ed., 17. (in Arabic).

Biswas, S.K., Tarafdar, S.A., Islam, A., Khaliquzzaman, M., Tervahattu, H. and Kupiainen, K. (2003) Impact of Unleaded Gasoline Introduction on the Concentration of lead in the Air of Dhaka, Bangladesh, J. Air Waste Manage. Assoc., 53: 1355-1362.

Braniš, M., Řezáčová, P. and Domasova, M. (2005) The effect of outdoor air and indoor human activity on mass concentrations of $\mathrm{PM}_{10}, \mathrm{PM}_{2.5}$, and $\mathrm{PM}_{1}$ in a classroom, Environ. Res., 99: 143-149.
Chao, C. Y. and Wong, K. K. (2002) Residential indoor PM10 and PM2.5 in Hong Kong and the elemental composition, Atmos Environ., 36: 265-277.

Chenchen, C., Weidong, C., Min, G., Mili, W., Gang, Y. and Xueyou, S. (2016) Law and features of TVOC and Formaldehyde pollution in urban indoor air, Atmospheric Environment, 132: 85-90.

Conner, T. L. and Williams, R. W. (2004) Identification of possible sources of particulate matter in the personal cloud using SEM/EDX, Atmos Environ., 38: 5305-5310.

Decree of the Flemish government (2004) of 11 June 2004 providing for measures aiming at controlling health risks caused by indoor pollution, Belg. Off. J., 19/10/2004.

Fernandez, A. J., Ternero, M., Barragán, F. J. and Jiménez, J. C. (2000) Chemosphere, 2, p.123.

Fromme, H., Diemer, J., Dietrich, S., Cyrys, J., Heinrich, J., Lang, W., Kiranoglu, M. and Twardella, D. (2008) Chemical and morphological properties of particulate matter $\left(\mathrm{PM}_{10}, \mathrm{PM}_{2.5}\right)$ in school classrooms and outdoor air, Atmos. Environ, 42: 6597-6605.

Grahame, T. J. and Schlesinger, R. B. (2010) Cardiovascular health and particulate vehicular emissions: a critical evaluation of the evidence, Air Qual Atmos Health, 3:3-27.

Gupta, A.K., Karar, K. and Srivastava, A. (2007) Chemical mass balance source apportionment of PM10 and TSP in residential and industrial sites of an urban region of Kolkata, India, J. Hazard. Mater., 142: 279-287.

Hays, S.M., Gobbell, R.V. and Gamick, N.R. (1995) Indoor Air Quality, Solution and Strategies. New York, McGrawHill Inc.

John, K., Karnae, S., Crist, K., Kim, M. Kulkarni, A. (2007) Analysis of trace elements and ions in ambient fine particulate matter at three elementary schools in Ohio. $J$. Air Waste Manag. Assoc. 57: 394-406.

Kornartit, C., Sokhi, R. S., Burton, M. A. and Ravindra, K. (2010) Activity pattern and personal exposure to nitrogen dioxide in indoor and outdoor microenvironments, Environ. Int., 36: 36-45.

Lee, S. C., Li, W. and Ao, C. H. (2002) Investigation of indoor air quality at residential homes in Hong Kong-case study, Atmos. Environ., 3: 225-237.

Levy, J.I., Dumyahn, T. and Spengler, J.D. (2002) Particulatematter and polycyclic aromatic hydrocarbon concentrations in indoor and outdoor microenvironments in Boston, Massachusetts, J. Expo. Anal. Environ. Epidemiol., 12: 104-114.

Molnár, P., Bellander, T., Sällsten, G. and Boman, J. (2007) Indoor and outdoor concentrations of $\mathrm{PM}_{2.5}$ trace elements at homes, preschools and schools in Stockholm, Sweden, J. Environ. Monit., 9: 348-357.

Molnár, P., Gustafson, P., Johannesson, S., Boman, J., Barregard, L. and Sãllsten, G. (2005) Domestic wood 
burning and $\mathrm{PM}_{2.5}$ trace elements: personal exposures, indoor and outdoor levels, Atmos. Environ. 39: 2643-2653.

Montgomery, D. D. and Kalman, D. A. (1989) Indoor/ outdoor air quality: Reference concentrations in complaint free residences, Appl. Ind Hyg., 4: 17-20.

Morawska, L., He, C., Hitchins, J., Gilbert, D. and Parappukkaran, S. (2001) The relationship between indoor and outdoor airborne particles in the residential environment, Atmos. Environ., 35: 3463-3473.

Nastov, J., Tan, R. and Dingle, P. (2003) The use of Fibre Technology to control surface Dust and Bacteria contamination Environ, Sci. Report Series, 1, Australia.

Paschold, H., Li, W.W., Morales, H., Pingitore, N. E. and Maciejewska, B. (2003) Elemental analysis of airborne particulate matter and cooling Water in west texas residences, Atmos. Environ., 37: 2681-2690.

Peiyao S., Lixin W., Yang H. and Rui L. (2015) PM2.5 Concentrations Indoors and Outdoors in Heavy Air Pollution Days in winter, Procedia Engineering, 121: 1902-1906.

Portaria n. ${ }^{\circ}$ 353-A/2013 de 4 de Dezembro, (2013) Requisitos de ventilação e qualidade do ar interior, Diário da República, $1^{\text {a }}$ série e N. ${ }^{\circ} 235-4$ de dezembro de 2013. Ministérios do Ambiente, Ordenamento do Território e Energia, da Saúde e da Solidariedade, Emprego e Segurança Social.

Ramachandran, G., et al. (2000) Comparison of short-term variations (15-minute averages) in outdoor and indoor PM2.5 concentrations, J. Air Waste Manag. Assoc, 50: $1157-1166$

Reisen, F., Meyer, C.P. and Keywood, M.D. (2013) Impact of biomass burning sources on seasonal air quality, Atmos. Environ, 67: 437-447.

Reto, M., Christian, S., Marloes, E., Inmaculada, A., Regina, E. D., Alex, I., Mark, D., Harish, C. P., Nicole, P., Ming-Yi, T. and Nino, K. (2015) Modeling indoor air pollution of outdoor origin in homes of SAPALDIA subjects in Switzerland, Environment International, 82: 85-91.

Schneider, T., Sundell, J., Bischof, W., Bohgard, M., Cherrie, J. W., Clausen, P.A., Dreborg, S., Kildeso, J., Kjaergaard, S. K., Lovik, M., Pasanen, P. and Skyberg, K. (2003) 'EUROPART' Airborne particles in the indoor environment, A European interdisciplinary review of scientific evidence on associations between exposure to particles in buildings and health effects, Indoor Air, 13: $38-48$.

Srivastava, A. and Jain, V.K. (2003) Relationships between Indoor and Outdoor Air Quality in Delhi, Indoor and Built Environ., 12: 19-165.

Stranger, M., Potgieter-Vermaak, S.S. and Van Grieken, R. (2007) Comparative overview of indoor air quality in Antwerp, Belgium. Environ. Int., 33: 789-797.

Stranger, M., Potgieter-Vermaak, S.S. and Van Grieken, R. (2008) Characterization of indoor air quality in primary schools in Antwerp, Belgium. Indoor Air, 18: 454-463.

Stranger, M., Potgieter-Vermaak, S.S. and VanGrieken, R. (2007) Comparative overview of indoor air quality in Antwerp, Belgium, Environ. Int., 33: 789-797.

Turiel, I. (1985) Indoor Air Quality and Human Health, Standford, CA, Standford University Press.

U. S. Environmental Protection Agency (EPA) (1996) Indoor Air Quality Office of Radiation and Indoor Air, Indoor Environments Division (6607 J) EPA - 402- F-96004 .

Yip, F. Y., Keeler, G. J., Dvonch, J. T., Robins, T. G., Parker, E. A., Israel, B. A. and Brakefield-Caldwell, W. (2004) Personal exposures to particulate matter among children with asthma in Detroit, Michigan. Atmos. Environ., 38: 5227-5236. 


\section{المحتوى العنصري للجسيمات العالقة الداخلية نتيجة لوسائل التذفئة المنزلية في مدينة سكاكا، المملكة العربية السعودية}

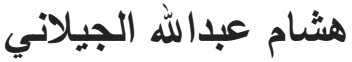

أستاذ مشارك بقسم العلوم البيئية بكلبة الأرصاد والبيئة وزراعة الدناطق الجافة، جامعة الملك عبدالعزبز،

$$
\text { جدة، المدلكة العربية السعودية }
$$

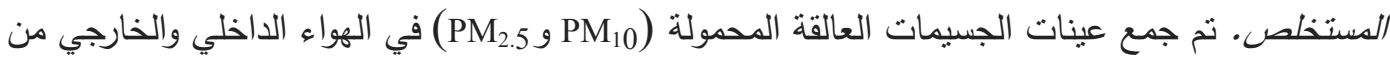
منازل مختلفة تستخدم وسائل التنفئة، تقع في مدينة سكاكا شمال المملكة، خلال موسم الثنتاء. التركيب

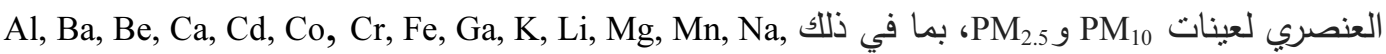
Inductively Coupled Plasma-mass ) تم تحليلها باستخدام التحليل الطيفي Ni, Pb, Se, Te and Tl EEL-type Smoke Stain أبضًا باستخدام) (BC) (Spectroscopy $\mathrm{PM}_{2.5}$ ـ Reflectometer

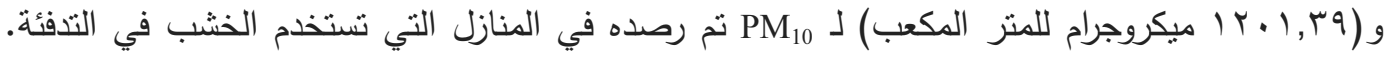

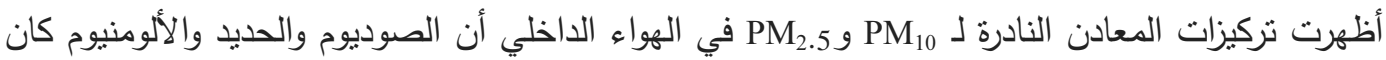
الأعلى تركيز، لوحظ أن أعلى تركيز للكربون الأسود وجد في المنازل التي تستخدم الخشب للتدفئة. في

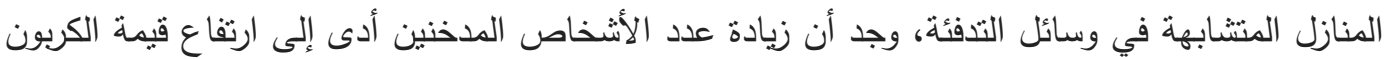

